\title{
Influence of prophylaxis paste treatment on the abrasive wear of surface sealants
}

\author{
Wegehaupt, Florian J ; Tauböck, Tobias T ; Attin, Thomas
}

\begin{abstract}
OBJECTIVE: To investigate the abrasive wear of surface sealants (SealProtect and K-0184 (experimental sealant)) and the influence of pre-treatment with mineral deposit forming prophylaxis pastes (NUPRO Sensodyne and NUPRO) on this wear. METHODS: One hundred and eight bovine dentine samples were randomly allocated to nine groups (1-9). Pre-treatment (10 s): groups 1-3: untreated, groups 4-6: NUPRO, groups 7-9: NUPRO Sensodyne. Sealing: groups 1, 4 and 7: unsealed, groups 2, 5 and 8: SealProtect, groups 3, 6 and 9: K-0184 (experimental sealer). Samples were then brushed with 12 000 brushing strokes (BS) with toothpaste slurry in an automatic brushing machine $(120 \mathrm{BS} / \mathrm{min} ; \mathrm{F}=$ $2.5 \mathrm{~N})$. Surface profiles were recorded at baseline, after pre-treatment and sealing and after each $2000 \mathrm{BS}$. RESULTS: Total profile change (wear or gain due to pre-treatment, treatment and 12000 BS): groups 1,4 and 7 (no surface sealant) showed a not significantly different wear of $18.48 \pm 2.63 \mu \mathrm{m}, 24.98 \pm$ $3.02 \mu \mathrm{m}$ and $21.50 \pm 5.47 \mu \mathrm{m}$, respectively. Remaining groups (sealed) showed a gain in height with no significant difference among each other. Wear in sealed groups (2, 3, 5, 6, 8 and 9) were not significantly different at all numbers of brushing strokes. Starting with $4000 \mathrm{BS}$, the wear in unsealed groups (1, 4 and 7) was statistically significantly higher compared to all other groups. CONCLUSION: Stability and wear resistance of surface sealants are not affected by pre-treatment of dentine with NUPRO Sensodyne. The surface sealants tested provide a stable protective surface layer on dentine, which lasts for at least 12000 brushing strokes.
\end{abstract}

DOI: https://doi.org/10.3109/00016357.2012.715201

Posted at the Zurich Open Repository and Archive, University of Zurich

ZORA URL: https://doi.org/10.5167/uzh-87922

Journal Article

Accepted Version

Originally published at:

Wegehaupt, Florian J; Tauböck, Tobias T; Attin, Thomas (2013). Influence of prophylaxis paste treatment on the abrasive wear of surface sealants. Acta Odontologica Scandinavica, 71(3-4):744-750.

DOI: https://doi.org/10.3109/00016357.2012.715201 
Influence of prophylaxis paste treatment on the abrasive wear of surface sealants.

FLORIAN J. WEGEHAUPT*1 ${ }^{1}$, TOBIAS T. TAUBÖCK ${ }^{1} \&$ THOMAS ATTIN $^{1}$

${ }^{1}$ Department for Preventive Dentistry, Periodontology and Cariology University of Zurich, Plattenstrasse 11, CH-8032 Zürich (Switzerland)

\section{*Corresponding author:}

Dr. Florian Wegehaupt

Department for Preventive Dentistry, Periodontology and Cariology, University of Zurich

Plattenstrasse 11

CH-8032 Zürich (Switzerland)

Tel. +41 44634 3354, Fax. +4144634 4308,

E-Mail: florian.wegehaupt@,zzm.uzh.ch

Short title: Abrasion of sealants

Word count abstract: 250

Figures: 1

Tables: 3 


\section{Abstract:}

Objective: To investigate the abrasive wear of surface sealants (Seal\&Protect and K-0184 (experimental sealant)) and the influence of pre-treatment with mineral deposit forming prophylaxis pastes (NUPRO Sensodyne and NUPRO) on this wear.

Methods: 108 bovine dentine samples were randomly allocated to nine groups (1-9). Pretreatment (10 s): groups 1-3: untreated, groups 4-6: NUPRO, groups 7-9: NUPRO Sensodyne. Sealing: groups 1, 4 and 7: unsealed, groups 2, 5 and 8: Seal\&Protect, groups 3, 6 and 9: K-0184 (experimental sealer). Samples were then brushed with 12000 brushing strokes (BS) with toothpaste slurry in an automatic brushing machine $(120 \mathrm{BS} / \mathrm{min} ; \mathrm{F}=2.5 \mathrm{~N})$. Surface profiles were recorded at baseline, after pre-treatment and sealing, and after each $2000 \mathrm{BS}$.

Results: Total profile change (wear or gain due to pre-treatment, treatment and $12000 \mathrm{BS}$ ): groups 1, 4 and 7 (no surface sealant) showed a not significantly different wear of $18.48 \pm 2.63$ $\mu \mathrm{m}, 24.98 \pm 3.02 \mu \mathrm{m}$ and $21.50 \pm 5.47 \mu \mathrm{m}$, respectively. Remaining groups (sealed) showed a gain in height with no significant difference among each other.

Wear in sealed groups $(2,3,5,6,8$ and 9) were not significantly different at all numbers of brushing strokes. Starting with $4000 \mathrm{BS}$, the wear in unsealed groups (1, 4 and 7) was statistically significantly higher compared to all other groups.

Conclusion: Stability and wear resistance of surface sealants are not affected by pre-treatment of dentine with NUPRO Sensodyne. The surface sealants tested provide a stable protective surface layer on dentine, which lasts for at least 12000 brushing strokes.

Key words: abrasion, dentine, prophylaxis paste, surface sealant 


\section{Introduction:}

The number of teeth still in use in higher age patients has increased over the last decades. With increasing age the percentage of gingival recessions with an exposure of root dentine to the oral environment increases also [1]. This exposed root dentine, especially when it is additionally softened due to erosion, is especially prone to abrasion during daily toothbrushing [2].

Furthermore, it is suggested that gingiva recessions are a major predisposing factor for dentine hypersensitivity [3]. Dentine hypersensitivity is caused by a change in fluid flow within the dentine tubules [4]. A very high prevalence (up to 98\%) of dentine hypersensitivity has been reported in patients following periodontal treatment [5], resulting in exposed root dentine with open dentine tubules. To overcome the problem of dentine hypersensitivity, the occlusion of open dentine tubules by blocking the hydrodynamic mechanism or by interruption of the neural response has been proposed among other suggestions. The occlusion of the dentine tubules might be achieved by a deposition of thin film coatings, such as restorative resins or dentine bonding agents $[6,7]$ or by formation of a mineral deposit on the exposed dentine and within the open dentine tubules [8]. To induce this mineral formation on dentine, prophylaxis pastes or toothpastes with different active ingredients like bioactive glass (NovaMin) $[9,10]$ or arginine and calcium carbonate [8] have been developed in the last decade.

In addition to gingiva recessions, dentine can also be exposed due to erosion from acidic food and drinks [11,12] and especially due to toothbrushing after an erosive challenge [13]. To prevent erosive enamel and/or dentine wear, different approaches like increasing the chemical resistance of the dental hard tissues [14] or rehardening of erosivly softened enamel or dentine [15] have been postulated. As with many of the preventive measures concerning erosion, prevention is highly dependent on patients' compliance. To overcome patient's dependency and to prevent erosion in patients, a coating of eroded teeth with a resin-based surface sealant has been suggested [16].

In both indications, prevention of dentine hypersensitivity and erosive tooth wear, the coating of exposed dentine with a resin based sealing material can only provide a positive effect as long as the coating is still intact on the dentine surface. As well as dentine, the coating can be abraded by 
toothbrushing or during mastication [17]. The stability of such a resin-based coating differs between different coating systems [17].

It is suggested that dental professionals might use a mineral formation inducing prophylaxis paste before application of a surface sealant to clean the dentine surface and additionally use the anti-hypersensitivity effects of these pastes. Furthermore, dental professionals might first use the anti-hypersensitivity prophylaxis pastes on exposed dentine to overcome dentine hypersensitivities but when not being satisfied by the effect use the surface sealants some time later. At this point, it is not possible to determine if some or all of the mineral deposit is still present on the dentine.

Taking in consideration this assumption and the above mentioned findings, the aim of the present study was to investigate the susceptibility of coating forming surface sealants against mechanical (abrasion) wear and the influence of the previous use of a mineral deposit forming prophylaxis paste on this wear property. The hypothesis was that the previous use of a mineral deposit forming prophylaxis paste results in a higher wear susceptibility of the surface sealants, as the interaction of the surface sealants during the application on the dentine surface and light curing might be influenced by the mineral deposit on the dentine surface.

\section{Materials and methods:}

\section{Sample preparation:}

For the study, 108 dentine samples were prepared from 12 freshly extracted cattles (age under 36 month) lower incisors. The teeth were sectioned at the cementum-enamel junction with a water-cooled diamante disc. The pulp tissue was removed from the roots with endodontic files.

Nine samples were gained with a trephine mill from the distal and mesial surface of each root. The inner diameter of the drill amounted to $3 \mathrm{~mm}$. The dentine cylinders were embedded in acrylic resin (Palavit G, Kulzer, Wehrheim, Germany) in metal moulds with an inner diameter of $6 \mathrm{~mm}$. The dentine surface was ground with abrasive paper $(800,1000,1200,2400$ and 4000 grit; Water Proof Silicon Carbide Paper, Struers, Erkrath, Germany) with running tap water as coolant. By this grinding step, the cementum was removed. To ensure that the dentine was free of cementum, all samples were checked under a light microscope. 
From each sample, five baseline surface profiles were recorded (Perthometer S2, Mahr, Göttingen, Germany) with a distance of $100 \mu \mathrm{m}$ between each profile. For exact repositioning of the samples during the experimental procedure, the profilometer is equipped with a custom-made jig [18].

After the sample preparation and recording of the baseline profiles, the samples were allocated to nine groups (1-9) with 12 samples per group.

\section{Pre-treatment and treatment of the samples:}

The samples of the groups $4-9$ were treated for 10 s per sample with the respective prophylaxis pastes (NUPRO or NUPRO Sensodyne, Dentsply Detrey GmbH, Konstanz, Germany). Samples of groups $4-6$ were polished with NUPRO (Nupro) and samples of groups 7 - 9 with NUPRO Sensodyne (Nupro S). The application was performed under constant and controlled pressure $(2.5 \mathrm{~N})$ with a rubber cup and a counter-angle handpiece. After the application, the samples were rinsed with tap water to remove excess material.

After this pre-treatment, the samples of the groups $2+3,5+6$ and $8+9$ were treated with protective surface sealants Seal\&Protect (Dentsply Detrey GmbH, Konstanz, Germany) or K-0184 (an experimental sealant; Dentsply Detrey GmbH, Konstanz, Germany). Before application of the sealants, the samples were covered with adhesive tape with a hole of $3 \mathrm{~mm}$ diameter, leaving only the dentine surface free, to prevent that sealant contaminates the embedding resin. The samples of groups 2, 5 and 8 were treated with Seal\&Protect (S\&P), while the samples of the groups 3, 6 and 9 were treated with the experimental sealant (K-0184). The respective sealants were applied on the dentine surface and left undisturbed for $20 \mathrm{~s}$. After these $20 \mathrm{~s}$ the remaining solvent was removed with a blow of an air syringe. Thereafter, the sealant was light-cured for 10 s (Bluephase, Ivoclar Vivadent, Liechtenstein; Mode: HIP, 1200 $\mathrm{mW} / \mathrm{cm} 2$ ). A second layer of sealant was applied, the remaining solvent was removed with an air syringe, and again light-curing was performed for $10 \mathrm{~s}$. After the application of the sealants, the adhesive tape for the protection of the resin was removed. The composition (manufactures information) of the used prophylaxis pastes and surface sealants is given in table 1. 
During the whole pre-treatment (application of the prophylaxis paste) and treatment process (application of surface sealants), the samples of group 1 remained untreated. They served as control group. Before starting the experimental process, all samples were stored in water for one week.

A short overview of the pre-treatment and treatment in the different groups is given in table 2 .

\section{Experimental procedure:}

After one week storage in water, the 1st measurement was performed to evaluate possible gain of height or wear due to the pre-treatment and treatment of the samples. For this measurement, again five profiles per sample of all groups were recorded.

For the simulation of toothbrush abrasion, the samples were then brushed with 2000 brushing strokes (BS) with toothpaste slurry in an automatic brushing machine applying reciprocating linear motion to the toothbrushes (ParoM43, Esro AG, Thalwil, Zürich, Switzerland). The brushing machine was adjusted to a constant brushing frequency of 120 strokes per minute and a constant brushing load of $2.5 \mathrm{~N}$. The toothpaste slurry was prepared by mixing $300 \mathrm{ml}$ artificial saliva [19] and $100 \mathrm{ml}$ toothpaste (elmex, Gaba, Münchenstein, Switzerland). After each 500 brushing strokes, the slurry was renewed. During the toothbrush abrasion, the samples were covered again with adhesive tape with a hole of $2 \mathrm{~mm}$ diameter so that the whole embedding resin and part of the dentine was again protected during the brushing. This protected area was used as reference area for the later superimposition of the profiles.

After $2000 \mathrm{BS}$, the samples were rinsed with water, the tape was removed and new profiles were recorded (2nd measurement).

The whole procedure of brushing (2000 BS) and measuring was repeated another five times, so that in the end, each sample was brushed with $12000 \mathrm{BS}$ and a total of 7 measurements were performed (before the first brushing and after 2000, 4000, 6000, 8000, 10000 and 12000 $\mathrm{BS})$.

The total wear or gain of height due to pre-treatment, treatment and the $12000 \mathrm{BS}$ (total heights change) was calculated by comparing the profiles of the baseline measurements (before 
pre-treatment and treatment) with the respective profiles of the final measurement 7 (after 12000 BS). The mean value of the five profiles per sample was calculated and used as respective value of that sample.

Furthermore, the wear due to the different numbers of brushing strokes $(2000,4000$, $6000,8000,10000$ and 12000) was calculated by comparing the profiles of measurements $2-7$ with the respective profiles of measurement 1 (after pre-treatment and treatment but before brushing). Again the mean value of the five profiles was calculated.

\section{Statistical Methods:}

Data were coded in EXCEL and analyzed with StatView Version 5.0.1 (SAS Institute Inc., Cary, N.C., USA) and SPSS Version 16.

Descriptive statistics such as mean and standard deviation (SD) together with the corresponding 95\% confidence interval (95\%CI) were computed for each group 1 - 9 and each number of strokes condition.

One-way ANOVA followed by Scheffé post-hoc test was used in order to investigate the differences in the mean total heights change between the different groups 1 - 9.

As a longitudinal development of wear with the number of strokes within each group happened, the plain wear within each group was analyzed by the repeated measures ANOVA (RM ANOVA) with Greenhouse-Geisser correction. Wear of different groups and within the same number of brushing strokes was compared with ANOVA and Scheffé post-hoc test.

Results of the statistical analyse with p-values smaller than $5 \%$ were interpreted as statistically significant.

\section{Results:}

\section{Total height change:}

The total height change (mean $\pm \mathrm{SD}$ ) (total wear or gain of heights due to pre-treatment, treatment and $12000 \mathrm{BS}$ ) of the groups $1-9$ is given in figure 1. Gain of height as compared to baseline meant, that sealant was still present on the dentine surface. In turn, wear meant that the 
original dentine surface was reduced by the application of the respective prophylaxis pastes and the later brushing procedure.

In groups 1, 4 and 7 (no application of a surface sealant) a negative total height change (= wear) was observed after $12000 \mathrm{BS}$. Wear in these groups amounted to $18.48 \pm 2.63 \mu \mathrm{m}, 24.98 \pm$ $3.02 \mu \mathrm{m}$ and $21.50 \pm 5.47 \mu \mathrm{m}$, respectively. No significant difference was observed within these groups ( $\mathrm{p}>0.05$, respectively).

All remaining groups (treated with a surface sealant) showed a positive total height change (= gain in height) after 12000 BS with no significant difference among each other $(\mathrm{p}>$ 0.05 , respectively). Lowest gain in height $(14.89 \pm 5.65 \mu \mathrm{m})$ was observed in group 6 (Nupro/K0184) while highest gain $(24.85 \pm 14.34 \mu \mathrm{m})$ was found in group 3 (no/K-0184).

Wear due to brushing:

The cumulative wear due to different numbers of brushing strokes in the different groups is given in table 3 .

Repeated measures ANOVA (RM ANOVA) with Greenhouse-Geisser correction showed a highly significant correlation between wear and number of brushing strokes within all groups $(\mathrm{p}<0.001$, respectively)

The wear of groups treated with a surface sealant (groups 2, 3, 5, 6, 8 and 9) were not significantly different at all numbers of brushing strokes, $(\mathrm{p}>0.05$, respectively). Starting with $4000 \mathrm{BS}$ the wear in the groups with no application of a surface sealant (1, 4 and 7$)$ was statistically significantly higher compared with the wear in all other groups $(\mathrm{p}<0.05$, respectively).

\section{Discussion:}

For the present study, dentine samples were prepared from bovine teeth. Numerous other studies investigating dentine wear by either tooth brushing [20,21], erosion [22,23] or combination of both $[2,24]$ also use bovine teeth to substitute human dentine. When using bovine teeth, it is easy to obtain more than one sample per tooth allowing allocation of samples from the same tooth to different experimental groups, thus increasing comparability between those groups 
[25]. Furthermore, sound bovine teeth, in contrast to human teeth, are easier to obtain in sufficient numbers [26]. Additionally, bovine teeth don`t have caries history, which might result in the formation of irregular dentine, influencing the reaction of the dentine with the applied surface sealants or the later tooth brushing abrasion. Recent studies showed, that there is no difference in the wear of human and bovine dentine due to tooth brush abrasion $[27,28]$.

In the present study, tooth brushing was performed up to 12000 brushing strokes. A recent study by Wiegand and Attin (2011) [25] assumed 10 - 15 brushing strokes per tooth during a single tooth brushing session being adequate to simulate the clinical condition in vitro. Taking in consideration these findings, the here performed brushing abrasion is equal to about 400 to 600 days in vivo, assuming twice tooth brushing daily.

The wear of the surface sealants and the unprotected dentine has been measured by profilometry. This method of quantification has been applied for these purposes in different other studies $[17,29,30]$. For the here used profilometer, a lower limit of measurements of $0.105 \mu \mathrm{m}$ has been determined, allowing an exact quantification of even the lowest wear $(0.82 \mu \mathrm{m})$ found in this study.

Limitation of the present study might be, that no erosive attack has been performed during the wear cycles. It has been shown [27] that the wear of dentine increases, when the erosive attacks are performed during the tooth brushing. This might result in an underestimation of the absolute wear, but as the present study intended to compare the wear performance after different kinds of pre-treatment and of different sealants, the absolute wear seems to be of less importance, as the values are only compared with each other and the untreated controls (relative values).

The hypothesis of the present study was that wear susceptibility of the surface sealants is higher when a mineral deposit forming prophylaxis paste has been applied on the dentine surface. This study hypothesis has to be rejected, since no significant difference in the wear performance of the surface sealants with or without prior application of the different prophylaxis pastes (NUPRO Sensodyne) or not (NUPRO), was observed. Reason for these findings might be that the mineral deposit on the dentine surface and in the dentine tubules might be incorporated in the surface sealant layer during its application and residence time. Such an incorporation of 
minerals in the resin could be assumed, as both sealants behave like self-etching materials, for which an embedding of apatite minerals, dissolved during application, is intended.

In the present study, the wear of the unsealed dentine was significantly higher compared with the wear of the surface sealants, irrespective the kind of sealant (Seal\&Protect or the experimental sealant). This finding is in accordance with the findings by Sundaram et al. (2007) [30]. In their in-vivo-study, the surface sealant Seal\&Protect was applied on the palatal surfaces of teeth with dentine exposed due to erosion/abrasion. The wear of sealed und unsealed teeth was measured at 3, 6, 12 and 24 months. Up to 6 months, the rate of wear of the control teeth (unsealed) was higher than those covered with Seal\&Protect [30].

In the present study, the wear of the used surface sealants due to tooth brushing abrasion with 12000 brushing strokes amounted to $1.52 \pm 0.51 \mu \mathrm{m}$ up to $2.69 \pm 1.07 \mu \mathrm{m}$. In contrast, the first in-vitro study [17] evaluating the possible protective effects of Seal\&Protect against erosive/abrasive tooth wear found a mean wear of Seal\&Protect of $2.79 \pm 21.51 \mu \mathrm{m}$ after 3000 cycles in a reciprocating ( $=6000$ brushing strokes) wear machine when samples were brushed with water. When samples were brushed while immersed in hydrochloric acid, a ten-fold higher wear was recorded $(24.8 \pm 57.4 \mu \mathrm{m})$. Considering the remaining thicknesses of the sealants in the present study (around $20 \mu \mathrm{m}$ after 12000 brushing strokes) and the wear of the sealants by the 12000 brushing strokes (around $2 \mu \mathrm{m}$ ) one might assume that the used sealants of the present study will only be removed when conditions used by Azzopardi et al. (2001) [17] are applied. However, under clinical situations, it seems to be unlikely that the sealed teeth will be brushed simultaneously while an erosion occurs. Differences in the absolute wear of the sealants might be attributed to differences in the used brushing forces and toothbrushes.

Furthermore, when taking in consideration the assumptions of Wiegand and Attin (2011) [25] that 10 - 15 brushing strokes per tooth during a single tooth brushing session being adequate to simulate the clinical condition in vitro, the conditions used by Azzopardi et al. (2001) (6000 brushing strokes) [17] will be reached in-vivo after 200 up to 300 days with tooth brushing twice a day. Therefore, one might assume that the surface sealants provide a protective effect against erosiv/abrasive wear [under the conditions used by Azzopardi et al. (2001)] for up to 200 to 300 days (6-10 month). 
Beside the commercial availably Seal\&Protect, also an experimental sealant was tested in the present study. The chemical composition of this sealant is the same as for Seal\&Protect with the only difference that no tricolsan is incorporated in the experimental sealant. Recent studies reported triclosan to be able to induce antibiotic resistances of different bacteria stems [31], to accumulate in human milk samples and in fish exposed to municipal wastewater [32] and to reduce serum thyroid hormone levels following oral administration [33]. Due to these findings, concerns about the use of triclosan as antimicrobial additive in personal care and sanitizing products arise. The easiest way to avoid possible negative side effects of triclosan is to refrain from incorporating it in products to be used in human subjects. As no significant difference in the cumulative wear due to brushing and the total height changes between Seal\&Protect and the triclosan free experimental sealant were observed, one might conclude that absence or presence of triclosan in the used sealants has no significant effect on its mechanical stability

\section{Conclusion:}

By the findings of the present study it might be concluded that a pre-treatment of dentine with a mineral deposing $[9,34]$ inducing prophylaxis paste (NUPRO Sensodyne) before application of the tested surface sealants does not affect stability and wear resistance of the applied surface sealant (Seal\&Protect or K-0184). Furthermore, surface sealants (Seal\&Protect and K-0184) provide a stable protective surface layer on dentine, which last for at least 12000 brushing strokes. 


\section{Acknowledgement:}

This study was supported by Dentsply Detrey GmbH, Konstanz, Germany. The funders had no role in study design, data collection and analysis, decision to publish, or preparation of the manuscript. 


\section{References:}

[1] Hugoson A, Sjodin B, Norderyd O. Trends over 30 years, 1973-2003, in the prevalence and severity of periodontal disease. J Clin Periodontol 2008;35:405-14.

[2] De Menezes M, Turssi CP, Hara AT, Messias DC, Serra MC. Abrasion of eroded root dentine brushed with different toothpastes. Clin Oral Investig 2004;8:151-5.

[3] Cummins D. Dentin hypersensitivity: from diagnosis to a breakthrough therapy for everyday sensitivity relief. J Clin Dent 2009;20:1-9.

[4] Brannstrom M, Linden LA, Astrom A. The hydrodynamics of the dental tubule and of pulp fluid. A discussion of its significance in relation to dentinal sensitivity. Caries Res $1967 ; 1: 310-7$.

[5] CH D. Dentine hypersensitivity-Dental hygiene and periodontal considerations. Int Dent J 2002;52:385-93.

[6] Kolker JL, Vargas MA, Armstrong SR, Dawson DV. Effect of desensitizing agents on dentin permeability and dentin tubule occlusion. J Adhes Dent 2002;4:211-21.

[7] Rusin RP, Agee K, Suchko M, Pashley DH. Effect of a new desensitizing material on human dentin permeability. Dent Mater 2010;26:600-7.

[8] Petrou I, Heu R, Stranick M, Lavender S, Zaidel L, Cummins D, Sullivan RJ, Hsueh C, Gimzewski JK. A breakthrough therapy for dentin hypersensitivity: how dental products containing $8 \%$ arginine and calcium carbonate work to deliver effective relief of sensitive teeth. J Clin Dent 2009;20:23-31.

[9] Burwell A, Jennings D, Muscle D, Greenspan DC. NovaMin and dentin hypersensitivity-in vitro evidence of efficacy. J Clin Dent 2010;21:66-71.

[10] Salian S, Thakur S, Kulkarni S, LaTorre G. A randomized controlled clinical study evaluating the efficacy of two desensitizing dentifrices. J Clin Dent 2010;21:82-7.

[11] Dababneh RH, Khouri AT, Addy M. Dentine hypersensitivity - an enigma? A review of terminology, mechanisms, aetiology and management. Br Dent J 1999;187:606-11; discussion 603.

[12] Zero DT, Lussi A. Erosion--chemical and biological factors of importance to the dental practitioner. Int Dent J 2005;55:285-90. 
[13] Attin T, Buchalla W, Gollner M, Hellwig E. Use of variable remineralization periods to improve the abrasion resistance of previously eroded enamel. Caries Res 2000;34:48-52.

[14] Wiegand A, Attin T. Influence of fluoride on the prevention of erosive lesions--a review. Oral Health Prev Dent 2003;1:245-53.

[15] Fowler CE, Gracia L, Edwards MI, Brown A, Rees GD. Fluoride penetration from toothpastes into incipient enamel erosive lesions investigated using dynamic secondary ion mass spectrometry. J Clin Dent 2009;20:186-91.

[16] Bartlett DW. The causes of dental erosion. Oral Dis 1997;3:209-11.

[17] Azzopardi A, Bartlett DW, Watson TF, Sherriff M. The measurement and prevention of erosion and abrasion. J Dent 2001;29:395-400.

[18] Attin T, Becker K, Roos M, Attin R, Paque F. Impact of storage conditions on profilometry of eroded dental hard tissue. Clin Oral Investig 2009;13:473-8.

[19] Klimek J, Hellwig E, Ahrens G. Effect of plaque on fluoride stability in the enamel after amine fluoride application in the artificial mouth. Dtsch Zahnarztl Z 1982;37:836-40.

[20] Imfeld T. Comparison of the mechanical effects of a toothbrush and standard abrasive on human and bovine dentine in vitro. J Clin Dent 2001;12:92-6.

[21] Wiegand A, Lemmrich F, Attin T. Influence of rotating-oscillating, sonic and ultrasonic action of power toothbrushes on abrasion of sound and eroded dentine. J Periodontal Res 2006;41:221-7.

[22] Wiegand A, Meier W, Sutter E, Magalhaes AC, Becker K, Roos M, Attin T. Protective effect of different tetrafluorides on erosion of pellicle-free and pellicle-covered enamel and dentine. Caries Res 2008;42:247-54.

[23] Hara AT, Karlinsey RL, Zero DT. Dentine remineralization by simulated saliva formulations with different Ca and Pi contents. Caries Res 2008;42:51-6.

[24] Magalhaes AC, Rios D, Moino AL, Wiegand A, Attin T, Buzalaf MA. Effect of Different Concentrations of Fluoride in Dentifrices on Dentin Erosion Subjected or Not to Abrasion in situ/ex vivo. Caries Res 2008;42:112-6.

[25] Wiegand A, Attin T. Design of erosion/abrasion studies--insights and rational concepts. Caries Res 2011;45 Suppl 1:53-9. 
[26] Oesterle LJ, Shellhart WC, Belanger GK. The use of bovine enamel in bonding studies. Am J Orthod Dentofacial Orthop 1998;114:514-9.

[27] Wegehaupt F, Gries D, Wiegand A, Attin T. Is bovine dentine an appropriate substitute for human dentine in erosion/abrasion tests? J Oral Rehabil 2008;35:390-4.

[28] Wegehaupt FJ, Widmer R, Attin T. Is bovine dentine an appropriate substitute in abrasion studies? Clin Oral Investig 2010;14:201-5.

[29] Azzopardi A, Bartlett DW, Watson TF, Sherriff M. The surface effects of erosion and abrasion on dentine with and without a protective layer. Br Dent J 2004;196:351-4; discussion 339.

[30] Sundaram G, Wilson R, Watson TF, Bartlett D. Clinical measurement of palatal tooth wear following coating by a resin sealing system. Oper Dent 2007;32:539-43.

[31] D'Arezzo S, Lanini S, Puro V, Ippolito G, Visca P. High-level tolerance to triclosan may play a role in Pseudomonas aeruginosa antibiotic resistance in immunocompromised hosts: evidence from outbreak investigation. BMC Res Notes 2012;5:43.

[32] Adolfsson-Erici M, Pettersson M, Parkkonen J, Sturve J. Triclosan, a commonly used bactericide found in human milk and in the aquatic environment in Sweden. Chemosphere 2002;46:1485-9.

[33] Paul KB, Hedge JM, DeVito MJ, Crofton KM. Short-term exposure to triclosan decreases thyroxine in vivo via upregulation of hepatic catabolism in Young Long-Evans rats. Toxicol Sci 2010;113:367-79.

[34] Burwell AK, Litkowski LJ, Greenspan DC. Calcium sodium phosphosilicate (NovaMin): remineralization potential. Adv Dent Res 2009;21:35-9. 


\section{Legends to tables an figures:}

Tab. 1: $\quad$ Composition of the used prophylaxis pastes and surface sealants (manufacturer's information).

Tab. 2: $\quad$ Overview of the pre-treatment $($ no $=$ no pre-treatment, Nupro $=$ NUPRO prophylaxis pastes and Nupro $\mathrm{S}=$ NUPRO Sensodyne prophylaxis paste) and treatment $($ none $=$ no application, $\mathrm{S} \& \mathrm{P}=$ Seal\&Protect and $\mathrm{K}-0184=$ experimental sealant) in the different groups.

Tab. 3: $\quad$ Mean cumulative wear in $\mu \mathrm{m}$ (SD) in groups $1-9$ at different numbers of brushing strokes. Values, within the same number of brushing strokes (read vertically), that are not statistically significantly different are marked with same capital letters.

Fig. 1: Total height changes (mean \pm SD) of the different groups (pretreatment/treatment). Positive values indicate height gain due to pre-treatment, treatment and 12000 BS while negative values indicate wear. Values that are not statistically significantly different are marked with same letters. 


\section{Tables:}

\begin{tabular}{|c|c|}
\hline Product & Composition \\
\hline $\begin{array}{l}\text { Nupro } \\
\text { (Dentsply Detrey, Konstanz, Germany) }\end{array}$ & $\begin{array}{l}\text { Sodium fluoride }(1.23 \% \text { fluoride ion }) \text { pumice, } \\
\text { glycerine, sodium silicate, methyl salicylate, } \\
\text { monosodium } \\
\text { carboxymethylcellulose, sodium saccharin, flavour, } \\
\text { water }\end{array}$ \\
\hline $\begin{array}{l}\text { Nupro Sensodyne } \\
\text { (Dentsply Detrey, Konstanz, Germany) }\end{array}$ & $\begin{array}{l}\text { sodium fluoride }(1.23 \% \text { fluoride ion), glycerine, } \\
\text { pumice, calcium sodium phosphosilicate } \\
\left(\text { NovaMin }{ }^{\circledR}\right), \text { sodium silicate, titanium dioxide, } \\
\text { methyl salicylate, } \\
\text { carboxymethylcellulose, sodium saccharin, flavour }\end{array}$ \\
\hline $\begin{array}{l}\text { Seal\&Protect } \\
\text { (Dentsply Detrey, Konstanz, Germany) }\end{array}$ & $\begin{array}{l}\text { Di- and trimethacrylate resins, PENTA } \\
\text { (dipentaerythritol penta acrylate monophosphate), } \\
\text { functionalised amorphous silica, photoinitiators, } \\
\text { butylated hydroxytoluene, cetylamine hydrofluoride, } \\
\text { triclosan, acetone }\end{array}$ \\
\hline $\begin{array}{l}\text { K-0184 } \\
\text { (Dentsply Detrey, Konstanz, Germany) }\end{array}$ & $\begin{array}{l}\text { Di- and trimethacrylate resins; PENTA } \\
\text { (dipentaerythritol penta acrylate monophosphate), } \\
\text { functionalised amorphous silica, photoinitiators, } \\
\text { butylated hydroxytoluene, cetylamine hydrofluoride, } \\
\text { acetone }\end{array}$ \\
\hline
\end{tabular}

Tab. 1: $\quad$ Composition of the used prophylaxis pastes and surface sealants (manufacturer's information). 


\begin{tabular}{|c|c|c|c|c|c|c|c|c|c|}
\hline & \multicolumn{9}{|c|}{ Group } \\
\hline & 1 & 2 & 3 & 4 & 5 & 6 & 7 & 8 & 9 \\
\hline Pre-treatment & no & no & no & Nupro & Nupro & Nupro & $\begin{array}{c}\text { Nupro } \\
\mathrm{S}\end{array}$ & $\begin{array}{c}\text { Nupro } \\
\mathrm{S}\end{array}$ & $\begin{array}{c}\text { Nupro } \\
\text { S }\end{array}$ \\
\hline Treatment & none & $\mathrm{S} \& \mathrm{P}$ & K-0184 & none & S\&P & K-0184 & none & $\mathrm{S} \& \mathrm{P}$ & K-0184 \\
\hline
\end{tabular}

Tab. 2: $\quad$ Overview of the pre-treatment $($ no $=$ no pre-treatment, Nupro $=$ NUPRO

prophylaxis pastes and Nupro $\mathrm{S}=$ NUPRO Sensodyne prophylaxis paste) and treatment $($ none $=$ no application, $\mathrm{S} \& \mathrm{P}=$ Seal\&Protect and $\mathrm{K}-0184=$ experimental sealant) in the different groups. 
Number of brushing strokes

\begin{tabular}{|c|c|c|c|c|c|c|c|c|c|}
\hline & \multirow[b]{2}{*}{ Pre-treatment } & \multirow[b]{2}{*}{ Treatment } & \multirow{2}{*}{\multicolumn{3}{|c|}{6000}} & \multirow{2}{*}{8000} & \multirow{2}{*}{10000} & \multirow{2}{*}{12000} \\
\hline & & & & & & & & & \\
\hline \multirow{9}{*}{ 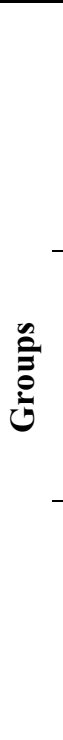 } & 1 & no & none & $\begin{array}{c}2.16 \\
(1.21) \mathrm{ABC}\end{array}$ & $\begin{array}{c}4.12 \\
(1.67) \mathrm{B}\end{array}$ & $\begin{array}{c}7.58 \\
(2.09) \mathrm{B}\end{array}$ & $\begin{array}{c}11.59 \\
(2.27) \mathrm{A}\end{array}$ & $\begin{array}{c}15.07 \\
(2.62) \mathrm{A}\end{array}$ & $\begin{array}{c}18.40 \\
(2.64) \mathrm{B}\end{array}$ \\
\hline & 2 & no & $S \& P$ & $\begin{array}{c}1.41 \\
(1.48) \mathrm{ABC}\end{array}$ & $\begin{array}{c}1.82 \\
(1.57) \mathrm{C}\end{array}$ & $\begin{array}{c}2.01 \\
(1.10) \mathrm{C}\end{array}$ & $\begin{array}{c}2.24 \\
(1.58) \mathrm{B}\end{array}$ & $\begin{array}{c}2.46 \\
(1.24) \mathrm{B}\end{array}$ & $\begin{array}{c}2.63 \\
(1.56) \mathrm{C}\end{array}$ \\
\hline & 3 & no & K-0184 & $\begin{array}{c}1.10 \\
(0.46) \mathrm{C}\end{array}$ & $\begin{array}{c}1.36 \\
(0.46) \mathrm{C}\end{array}$ & $\begin{array}{c}1.41 \\
(0.43) \mathrm{C}\end{array}$ & $\begin{array}{c}1.61 \\
(1.29) \mathrm{B}\end{array}$ & $\begin{array}{c}1.35 \\
(0.60) \mathrm{B}\end{array}$ & $\begin{array}{c}1.52 \\
(0.78) \mathrm{C}\end{array}$ \\
\hline & 4 & Nupro & none & $\begin{array}{c}2.81 \\
(1.05) \mathrm{A}\end{array}$ & $\begin{array}{c}6.55 \\
(1.45) \mathrm{A}\end{array}$ & $\begin{array}{c}10.59 \\
(1.92) \mathrm{A}\end{array}$ & $\begin{array}{c}14.16 \\
(2.12) \mathrm{A}\end{array}$ & $\begin{array}{c}18.22 \\
(2.75) \mathrm{A}\end{array}$ & $\begin{array}{c}23.76 \\
(3.29) \mathrm{A}\end{array}$ \\
\hline & 5 & Nupro & S\&P & $\begin{array}{c}1.28 \\
(0.42) \mathrm{C}\end{array}$ & $\begin{array}{c}1.60 \\
(0.33) \mathrm{C}\end{array}$ & $\begin{array}{c}1.94 \\
(0.50) \mathrm{C}\end{array}$ & $\begin{array}{c}1.94 \\
(0.49) \mathrm{B}\end{array}$ & $\begin{array}{c}2.30 \\
(0.58) \mathrm{B}\end{array}$ & $\begin{array}{c}2.47 \\
(0.52) \mathrm{C}\end{array}$ \\
\hline & 6 & Nupro & K-0184 & $\begin{array}{c}1.32 \\
(0.26) \mathrm{BC}\end{array}$ & $\begin{array}{c}1.67 \\
(0.35) \mathrm{C}\end{array}$ & $\begin{array}{c}1.62 \\
(0.22) \mathrm{C}\end{array}$ & $\begin{array}{c}1.82 \\
(0.58) \mathrm{B}\end{array}$ & $\begin{array}{c}2.10 \\
(0.84) \mathrm{B}\end{array}$ & $\begin{array}{c}2.32 \\
(1.03) \mathrm{C}\end{array}$ \\
\hline & 7 & Nupro $S$ & none & $\begin{array}{c}2.71 \\
(0.97) \mathrm{AB}\end{array}$ & $\begin{array}{c}6.26 \\
(2.12) \mathrm{A}\end{array}$ & $\begin{array}{c}9.64 \\
(2.78) \mathrm{AB}\end{array}$ & $\begin{array}{c}12.81 \\
(3.72) \mathrm{A}\end{array}$ & $\begin{array}{c}16.02 \\
(4.68) \mathrm{A}\end{array}$ & $\begin{array}{c}21.53 \\
(5.49) \mathrm{AB}\end{array}$ \\
\hline & 8 & Nupro $S$ & $S \& P$ & $\begin{array}{c}0.82 \\
(0.26) \mathrm{C}\end{array}$ & $\begin{array}{c}1.49 \\
(0.32) \mathrm{C}\end{array}$ & $\begin{array}{c}1.78 \\
(0.33) \mathrm{C}\end{array}$ & $\begin{array}{c}1.75 \\
(0.37) \mathrm{B}\end{array}$ & $\begin{array}{c}2.53 \\
(1.26) \mathrm{B}\end{array}$ & $\begin{array}{c}2.69 \\
(1.07) \mathrm{C}\end{array}$ \\
\hline & 9 & Nupro $S$ & K-0184 & $\begin{array}{c}0.94 \\
(0.27) \mathrm{C}\end{array}$ & $\begin{array}{c}1.04 \\
(0.43) \mathrm{C}\end{array}$ & $\begin{array}{c}1.25 \\
(0.32) \mathrm{C}\end{array}$ & $\begin{array}{c}1.07 \\
(0.48) \mathrm{B}\end{array}$ & $\begin{array}{c}1.45 \\
(0.45) \mathrm{B}\end{array}$ & $\begin{array}{c}1.52 \\
(0.51) \mathrm{C}\end{array}$ \\
\hline
\end{tabular}

Tab. 3: $\quad$ Mean cumulative wear of sealants or dentine in $\mu \mathrm{m}$ (SD) in groups $1-9$ at different numbers of brushing strokes. Values, within the same number of brushing strokes (read vertically), that are not statistically significantly different are marked with same capital letters. 


\begin{tabular}{|c|c|}
\hline Product & Composition \\
\hline $\begin{array}{l}\text { Nupro } \\
\text { (Dentsply Detrey, Konstanz, Germany) }\end{array}$ & $\begin{array}{l}\text { Sodium fluoride }(1.23 \% \text { fluoride ion). pumice, } \\
\begin{array}{l}\text { glycerine, sodium silicate, methyl salicylate, } \\
\text { monosodium } \\
\text { phosphate, }\end{array} \\
\begin{array}{l}\text { carboxymethylcellulose, sodium saccharin, flavour, } \\
\text { water }\end{array}\end{array}$ \\
\hline $\begin{array}{l}\text { Nupro Sensodyne } \\
\text { (Dentsply Detrey, Konstanz, Germany) }\end{array}$ & \begin{tabular}{l} 
sodium fluoride $(1.23 \%$ fluoride ion), glycerine, \\
pumice, calcium sodium phosphosilicate \\
(NovaMin $\AA)$, sodium silicate, titanium dioxide, \\
methyl salicylate, \\
\multicolumn{4}{l}{ carboxymethylcellulose, sodium saccharin, flavour }
\end{tabular} \\
\hline $\begin{array}{l}\text { Seal\&Protect } \\
\text { (Dentsply Detrey, Konstanz, Germany) }\end{array}$ & $\begin{array}{l}\text { Di- and trimethacrylate resins, PENTA } \\
\text { (dipentaerythritol penta acrylate monophosphate), } \\
\text { functionalised amorphous silica, photoinitiators, } \\
\text { butylated hydroxytoluene, cetylamine hydrofluoride, } \\
\text { triclosan, acetone }\end{array}$ \\
\hline $\begin{array}{l}\text { K-0184 } \\
\text { (Dentsply Detrey, Konstanz, Germany) }\end{array}$ & $\begin{array}{l}\text { Di- and trimethacrylate resins; PENTA } \\
\text { (dipentaerythritol penta acrylate monophosphate), } \\
\text { functionalised amorphous silica, photoinitiators, } \\
\text { butylated hydroxytoluene, cetylamine hydrofluoride, } \\
\text { acetone }\end{array}$ \\
\hline
\end{tabular}

Tab. 1: Composition of the used prophylaxis pastes and surface sealants (manufacturer's information). 


\begin{tabular}{c|c|c|c|c|c|c|c|c|c} 
& $\mathbf{1}$ & $\mathbf{2}$ & $\mathbf{3}$ & $\mathbf{4}$ & $\mathbf{5}$ & $\mathbf{6}$ & $\mathbf{7}$ & $\mathbf{8}$ & $\mathbf{9}$ \\
\hline Pre-treatment & no & no & no & Nupro & Nupro & Nupro & Nupro & Nupro & Nupro \\
& & & & & & & S & S & S \\
\hline Treatment & none & S\&P & K-0184 & none & S\&P & K-0184 & none & S\&P & K-0184
\end{tabular}

Tab. 2: $\quad$ Overview of the pre-treatment $($ no $=$ no pre-treatment, Nupro $=$ NUPRO

prophylaxis pastes and Nupro $\mathrm{S}=$ NUPRO Sensodyne prophylaxis paste) and treatment $($ none $=$ no application, $\mathrm{S} \& \mathrm{P}=$ Seal\&Protect and $\mathrm{K}-0184=$ experimental sealant) in the different groups. 
Number of brushing strokes

\begin{tabular}{|c|c|c|c|c|c|c|c|c|c|}
\hline & \multirow[b]{2}{*}{ Pre-treatment } & \multirow[b]{2}{*}{ Treatment } & \multirow{2}{*}{\multicolumn{3}{|c|}{6000}} & \multirow{2}{*}{8000} & \multirow{2}{*}{10000} & \multirow{2}{*}{12000} \\
\hline & & & & & & & & & \\
\hline \multirow{9}{*}{ 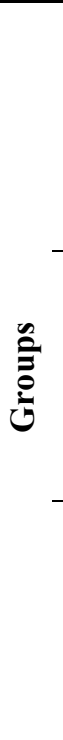 } & 1 & no & none & $\begin{array}{c}2.16 \\
(1.21) \mathrm{ABC}\end{array}$ & $\begin{array}{c}4.12 \\
(1.67) \mathrm{B}\end{array}$ & $\begin{array}{c}7.58 \\
(2.09) \mathrm{B}\end{array}$ & $\begin{array}{c}11.59 \\
(2.27) \mathrm{A}\end{array}$ & $\begin{array}{c}15.07 \\
(2.62) \mathrm{A}\end{array}$ & $\begin{array}{c}18.40 \\
(2.64) \mathrm{B}\end{array}$ \\
\hline & 2 & no & $S \& P$ & $\begin{array}{c}1.41 \\
(1.48) \mathrm{ABC}\end{array}$ & $\begin{array}{c}1.82 \\
(1.57) \mathrm{C}\end{array}$ & $\begin{array}{c}2.01 \\
(1.10) \mathrm{C}\end{array}$ & $\begin{array}{c}2.24 \\
(1.58) \mathrm{B}\end{array}$ & $\begin{array}{c}2.46 \\
(1.24) \mathrm{B}\end{array}$ & $\begin{array}{c}2.63 \\
(1.56) \mathrm{C}\end{array}$ \\
\hline & 3 & no & K-0184 & $\begin{array}{c}1.10 \\
(0.46) \mathrm{C}\end{array}$ & $\begin{array}{c}1.36 \\
(0.46) \mathrm{C}\end{array}$ & $\begin{array}{c}1.41 \\
(0.43) \mathrm{C}\end{array}$ & $\begin{array}{c}1.61 \\
(1.29) \mathrm{B}\end{array}$ & $\begin{array}{c}1.35 \\
(0.60) \mathrm{B}\end{array}$ & $\begin{array}{c}1.52 \\
(0.78) \mathrm{C}\end{array}$ \\
\hline & 4 & Nupro & none & $\begin{array}{c}2.81 \\
(1.05) \mathrm{A}\end{array}$ & $\begin{array}{c}6.55 \\
(1.45) \mathrm{A}\end{array}$ & $\begin{array}{c}10.59 \\
(1.92) \mathrm{A}\end{array}$ & $\begin{array}{c}14.16 \\
(2.12) \mathrm{A}\end{array}$ & $\begin{array}{c}18.22 \\
(2.75) \mathrm{A}\end{array}$ & $\begin{array}{c}23.76 \\
(3.29) \mathrm{A}\end{array}$ \\
\hline & 5 & Nupro & S\&P & $\begin{array}{c}1.28 \\
(0.42) \mathrm{C}\end{array}$ & $\begin{array}{c}1.60 \\
(0.33) \mathrm{C}\end{array}$ & $\begin{array}{c}1.94 \\
(0.50) \mathrm{C}\end{array}$ & $\begin{array}{c}1.94 \\
(0.49) \mathrm{B}\end{array}$ & $\begin{array}{c}2.30 \\
(0.58) \mathrm{B}\end{array}$ & $\begin{array}{c}2.47 \\
(0.52) \mathrm{C}\end{array}$ \\
\hline & 6 & Nupro & K-0184 & $\begin{array}{c}1.32 \\
(0.26) \mathrm{BC}\end{array}$ & $\begin{array}{c}1.67 \\
(0.35) \mathrm{C}\end{array}$ & $\begin{array}{c}1.62 \\
(0.22) \mathrm{C}\end{array}$ & $\begin{array}{c}1.82 \\
(0.58) \mathrm{B}\end{array}$ & $\begin{array}{c}2.10 \\
(0.84) \mathrm{B}\end{array}$ & $\begin{array}{c}2.32 \\
(1.03) \mathrm{C}\end{array}$ \\
\hline & 7 & Nupro $S$ & none & $\begin{array}{c}2.71 \\
(0.97) \mathrm{AB}\end{array}$ & $\begin{array}{c}6.26 \\
(2.12) \mathrm{A}\end{array}$ & $\begin{array}{c}9.64 \\
(2.78) \mathrm{AB}\end{array}$ & $\begin{array}{c}12.81 \\
(3.72) \mathrm{A}\end{array}$ & $\begin{array}{c}16.02 \\
(4.68) \mathrm{A}\end{array}$ & $\begin{array}{c}21.53 \\
(5.49) \mathrm{AB}\end{array}$ \\
\hline & 8 & Nupro $S$ & $S \& P$ & $\begin{array}{c}0.82 \\
(0.26) \mathrm{C}\end{array}$ & $\begin{array}{c}1.49 \\
(0.32) \mathrm{C}\end{array}$ & $\begin{array}{c}1.78 \\
(0.33) \mathrm{C}\end{array}$ & $\begin{array}{c}1.75 \\
(0.37) \mathrm{B}\end{array}$ & $\begin{array}{c}2.53 \\
(1.26) \mathrm{B}\end{array}$ & $\begin{array}{c}2.69 \\
(1.07) \mathrm{C}\end{array}$ \\
\hline & 9 & Nupro $S$ & K-0184 & $\begin{array}{c}0.94 \\
(0.27) \mathrm{C}\end{array}$ & $\begin{array}{c}1.04 \\
(0.43) \mathrm{C}\end{array}$ & $\begin{array}{c}1.25 \\
(0.32) \mathrm{C}\end{array}$ & $\begin{array}{c}1.07 \\
(0.48) \mathrm{B}\end{array}$ & $\begin{array}{c}1.45 \\
(0.45) \mathrm{B}\end{array}$ & $\begin{array}{c}1.52 \\
(0.51) \mathrm{C}\end{array}$ \\
\hline
\end{tabular}

Tab. 3: $\quad$ Mean wear of sealants or dentine in $\mu \mathrm{m}$ (SD) in groups $1-9$ at different numbers of brushing strokes. Values, within the same number of brushing strokes (read vertically), that are not statistically significantly different are marked with same capital letters. 